\title{
Corticosteroid-Induced Central Serous Chorioretinopathy
}

\author{
Korioretinopati Serosa Sentral yang Diinduksi Corticosteroid
}

\author{
Ade John Nursalim*, Vera Sumual \\ Ophthalmology Department, Prof. Dr. R.D. Kandou Central General Hospital, Jalan Raya Tanawangko No.56, Malalayang \\ Satu Barat, Malalayang, Manado, North Sulawesi, Indonesia.
}

DATA OF ARTICLE:

Received: 28 Mei 2019

Reviewed: 9 Nov 2019

Revised: 9 Des 2019

Accepted: 31 Des 2019

*CORRESPONDENCE:

dr.adejn@gmail.com

DOI:

$10.18196 / \mathrm{mm} .200142$

TYPE OF ARTICLE: Case Report

\begin{abstract}
Central Serous Chorioretinopathy (CSC) is a condition where there is an accumulation of serous fluid in the retinal pigment epithelium layer. The abnormality in the retinal pigment layer of the eye causes vision loss and serous detachment. CSC has a variety of causes, one of which is corticosteroid therapy. This article aims to report a case of a 27-year-old male patient who was diagnosed with CSC. The risk factor indicating CSC, in this case, was long-term oral and the use of a nasal spray to treat patient's allergic rhinitis. Patients have allergic rhinitis and sneezing. Thus, they are administered to consume tablets of $16 \mathrm{mg}$ methylprednisolone three times a day. The patient has a history of using a nasal spray containing $0.05 \%$ mometasone furoate monohydrate for ten years in a row. The patient's visual acuity is $6 / 6$ on his right eye and $6 / 15$ on his left eye. Posterior segment examination and optical coherence tomography (OCT) were considered effective in identifying the features of patients with CSC, and thus both were administered. It was further found that steroid therapy replacement and healthier lifestyle adjustments could sustain the symptoms and improve the patient's wellbeing.
\end{abstract}

Keywords: Central Serous Chorioretinopathy; Long term steroid; Methylprednisolone; Mometasone furoate

\begin{abstract}
Abstrak: Central Serous Chorioretinopathy (CSC) adalah suatu kondisi di mana terdapat akumulasi cairan serosa dalam lapisan epitel pigmen retina yang dapat menyebabkan terlepasnya lapisan neurosensori retina. CSC memiliki berbagai penyebab termasuk terapi kortikosteroid. Artikel ini ditulis untuk melaporkan seorang pria dengan diagnosis CSC. Faktor risiko untuk CSC dalam kasus ini adalah penggunaan steroid oral dan semprotan nasal jangka panjang karena rinitis alergi. Pasien memiliki rinitis alergi dan bersin dan terbiasa menggunakan tablet metilprednisolon $16 \mathrm{mg}$ tiga kali sehari ketika ia merasa alergi. Pasien memiliki riwayat menggunakan semprotan hidung yang mengandung 0,05\% mometasone furoate monohydrate selama 10 tahun berturut-turut. Ketajaman visual pasien masing-masing adalah 6/6 dan 6/15 untuk mata kanan dan kiri dengan beberapa fitur CSC dalam pemeriksaan segmen posterior dan Optical Coherence Tomography (OCT). Penggantian terapi steroid dan modifikasi gaya hidup menurunkan gejala dan kualitas hidup pasien.
\end{abstract}

Kata Kunci : Korioretinopati serosa sentral; Methylprednisolone; Mometasone furoate; Steroid jangka panjang 


\section{INTRODUCTION}

Central Serous Chorioretinopathy (CSC) is the fourth most non-surgical retinopathy after agerelated macular degeneration (AMD), diabetic retinopathy (DR), and Branch Retinal Vein Occlusion (BRVO). ${ }^{1} \quad$ Males have a higher prevalence of CSC than female according to some literature reports. ${ }^{2-4}$

Central Serous Chorioretinopathy (CSC) is a condition where there is an accumulation of serous fluid in the $r$ etinal pigment epithelium layer, which causes detachment of the retinal neurosensory. CSC has a variety of causes and is usually related to several conditions. Middle age, type A personality, narcissistic personality, corticosteroid therapy, post vitrectomy surgery, heart, spinal cord and kidney transplant, conditions involving cortisol such as Cushing's disease and pregnancy, hypertension, sleep apnea, smoking, alcohol consumption, antihistamines, asthma to gastroesophageal reflux (GERD) are known to be a risk factor for CSC. ${ }^{5}$ This article aims to report a man with a CSC diagnosed with risk factors for long-term oral steroid use. from non-communicable diseases such as cancer, heart disease, stroke and DM. ${ }^{6,7}$

\section{CASES}

A 27-year-old man came with a complaint of left eye blurred in the last one week. The patient experienced an indistinct vision for two days straight. The decrease in visual acuity in the mentioned patient was accompanied by dizziness when seeing with both eyes. Patients had allergic rhinitis and sneezing and were accustomed to using tablets of methylprednisolone $16 \mathrm{mg}$ three times a day when he felt the allergic reactions. This habit has been carried out by patients for about ten years. The patient also had a history of using a nasal spray containing $0.05 \%$ mometasone furoate monohydrate, which was used when the patient's nose felt congested. The patient did not have a history of high blood pressure, diabetes, or cholesterol.

Ophthalmology examination results showed visual acuity of the right eye was $6 / 6$, and the left eye was $6 / 15$. The results of a field examination with confrontation showed no peripheral visual field disturbances in both eyes. The results of the examination with Goldman perimetry showed a normal vision in the right eye and a central scotoma in the left eye. Intraocular pressure for both eyes was 15. Examination using the Amsler grid showed metamorphopsia in the left eye vision. The posterior segment examined by using indirect ophthalmoscopy with a 20 D lens in both eyes revealed different images. The posterior segment of the patient's right eye showed within normal limits with a uniform fundus reflex, a clear border of the optic nerve, and vital color with 0.3 cup disc ratio (CDR). The patient's left eye retina showed a picture of minimal edema with a yellowish circle with unclear boundaries with a normal disc appearance (Figure 1). The patient was consulted for an examination of Optical Coherence Tomography (OCT). OCT examination showed subretinal fluid with the 285-micrometer central retinal thickness (Figure 2 ).

The patient was diagnosed with right eye emmetropia and central serous left eye chorioretinopathy with allergic rhinitis. The management of this patient was vitamin B6 three times daily and is administered to the Ear Nose Throat and neck (ENT) department for further treatment of allergic rhinitis. The patient was also given information regarding the patient's eye disease and steroid use as a risk factor and was advised not to use methylprednisolone tablets without a doctor's prescription.

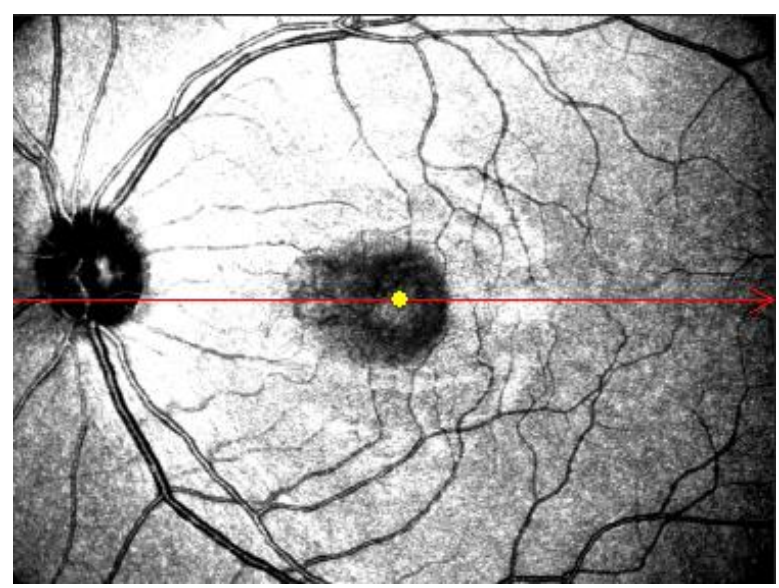

Figure 1. Fundus Photo of the left eye.

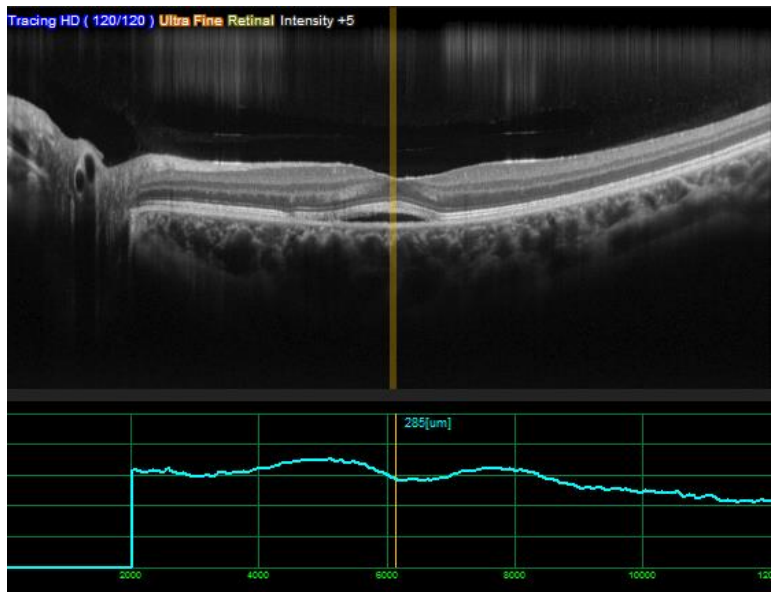

Figure 2. OCT examination report 
Upon the two-month therapy, the patient came back with the left eye's vision condition to be improved. Mometasone furoate monohydrate of $0.05 \%$ nasal spray was changed to $0.1 \%$ of Xylometazoline HCL. On the ophthalmology examination, the patient's right and left eye visual acuity were 6/6. The examination with the Amsler grid did not show any metamorphopsia in both eyes. The results of the cross-section with Goldman perimetry showed a normal visual condition in both eyes. The posterior segment of both eyes showed a uniform fundus reflex, a clear border of the optic nerve, vital color with cup disc ratio 0.3 , as well as retina and macula within normal limits. The results of the left eye OCT examination showed normal OCT with a macular thickness of 227 micrometers for the left eye. The patient was subsequently diagnosed with right eye emmetropia and the left eye central Serous Chorioretinopathy with improvement.

\section{DISCUSSION}

CSC is a retinal disease characterized by an accumulation of subretinal fluid. This buildup of fluid can cause retinal detachment, which ultimately disrupts vision that leads to blindness. Choriocapillaris malfunction, choroidal hyperpermeability, and abnormal choroidal thickness are believed to be the main pathologies of CSC. ${ }^{6}$ This patient, a respondent in this study, used Mometasone Furoate as a nasal spray. It has been a habit for the past 10 years. Methylprednisolone and Mometasone Furoate are derivatives of Glucocorticoid hormone, which acts like a hormone produced by the adrenal cortex. ${ }^{7}$ Inhaled glucocorticoids can be absorbed into the body and have a systemic effect. This absorption is influenced by various factors, including corticosteroid particle size, absorption, and metabolism of the drugs consumed. ${ }^{8} \quad$ Inhaled corticosteroids have the potential to be absorbed into the systemic circulation as much as $13-39 \% .9$

Corticosteroids are one of the most frequent therapeutic choices in handling allergic cases. On the other hand, the use of corticosteroids results in inhibition of neutrophil attachment to the endothelium, a decrease in chemotaxis from neutrophils and monocytes, and inhibition of phagocytosis and intercellular resistance to microorganisms. Other side effects of corticosteroid use include Cushing's syndrome, peptic ulcer disease, benign intracranial hypertension, psychosis, glaucoma, posterior subcapsular cataracts, paraplegia, hypertension, diabetic ketoacidosis, hyperglycemia, myopathy, osteoporosis, and also as included in this case report, central serous chorioretinopathy. ${ }^{10-27}$

Although the pathophysiology of CSC is still unclear, it is identified that glucocorticoid hormones work by binding to glucocorticoid receptors. This hormone is produced in the adrenal cortex and retinal pigment epithelium. It results in high concentrations of glucocorticoid hormones in the eyeball compared to blood plasma. ${ }^{28}$ Glucocorticoid derivatives in the eye are such as cortisol. A function of the hormone cortisol is such as maintaining homeostasis. ${ }^{29}$ Excessive hormone cortisol results in hyperpermeability of the choroid blood vessels, eventually increasing hydrostatic tissue pressure and ultimately damaging the barrier function of the retinal pigment epithelium. This increase can result in damage to the retinal fragment epithelium, which leads to an accumulation of subretinal fluid. ${ }^{2}$ This finding is in line with the findings on the examination of the posterior segment of the patient where it revealed an appearance of minimal edema with a yellowish circle with unclear boundaries.

Further examination performed on this patient was an Optical Coherence Tomography (OCT) examination. OCT is the latest modality in ophthalmology to examine a retina. This OCT shows a cross-section of the retina and is non-invasive, and thus it is safe to use in diagnostic enforcement. ${ }^{30,31}$ The OCT findings in this patient were in the form of subretinal fluid which was a marker of diagnosis of CSC. 5

The treatment given to these patients was 10mg pyridoxine (vitamin B6) tablet three times a day. This dose is below the daily recommended dose of 1-25 mg. In addition, to function as a nerve protector, pyridoxine is also useful as a placebo effect in patients while waiting for an increase in disease. ${ }^{32}$ Long-term administration of pyridoxine can lead to toxicity of pyridoxine in the skin, digestive tract, and nervous system. Thus, vitamin B6 is needed in amino acid metabolism, carbohydrates and lipids. The side effects of pyridoxine can also be neuropathy including, hypoesthesia, paraesthesia, peripheral neuropathy, muscle weakness, disturbances in walking and balance, and other complaints. $33-35$ CSC can lead to blindness, but it can also heal on its own within 3-4 months in some cases. ${ }^{5}$ Therefore, other therapies other than Piridoxin are not given to these patients. ${ }^{36}$ The condition of stress and depression in patients contributes to increased cortisol levels. ${ }^{23}$ Stress that induced CSC can occur in any profession, including medical workers. Stress management was 
one of the non-pharmacological management for CSC. 37

\section{CONCLUSION}

Posterior segment examination and optical coherence tomography were considered effective in identifying the features of patients with CSC, and thus, both were administered. It was further revealed that steroid therapy replacement and healthier lifestyle adjustments could sustain the symptoms and improve the patient's well-being.

\section{REFERENCES}

1. Wang, M., Munch, I. C., Hasler, P. W., Prünte, C., \& Larsen, M. Central serous chorioretinopathy. Acta ophthalmologica. 2008, 86(2), 126-145.

2. Liegl, R., \& Ulbig, M. W. Central serous chorioretinopathy. Ophthalmologica. 2014, 232(2), 65-76.

3. Riaz MT. Different Patterns of Central Serous Chorio-retinopathy on Fundus Fluorescein Angiography. In Islamabad Congress of Ophthalmology. 2017 Apr (Vol. 15, No. 2, p. 65).

4. Nicholson, B., Noble, J., Forooghian, F., \& Meyerle, C. Central serous chorioretinopathy: update on pathophysiology and treatment. Survey of ophthalmology. 2013, 58(2), 103-126.

5. Schachat, A. P., Wilkinson, C. P., Hinton, D. R., Wiedemann, P., Freund, K. B., \& Sarraf, D. Ryan's retina e-book. Elsevier Health Sciences. 2017.

6. Schubert, H. D., Atebara, N. H., Kaiser, R. S., Martidis, A. A., McCannel, C. A., \& Zacks, D. N. Basic and clinical science course, section 12: retina and vitreous, 2014-2015. San Francisco, CA: American Academy of Ophthalmology. 2014.

7. Ciprandi, G., \& Varricchio, A. The relevance of the Mometasone furoate nasal spray in clinical practice. Journal of biological regulators and homeostatic agents, 2018, 32(4), 1051-1054.

8. Allen, D. B. Sense and sensitivity: assessing inhaled corticosteroid effects on the hypothalamicpituitary-adrenal axis. Annals of Allergy, Asthma $\mathcal{E}$ Immunology, 2002, 89(6), 537-539.

9. Harrison, T. W., Wisniewski, A., Honour, J., \& Tattersfield, A. E. Comparison of the systemic effects of fluticasone propionate and budesonide given by dry powder inhaler in healthy and asthmatic subjects. Thorax, 2001, 56(3), 186-191.

10. Notay, M., Fazel, N., \& Awasthi, S. Cushing syndrome induced by topical corticosteroids for the treatment of lichen sclerosus. Journal of pediatric and adolescent gynecology, 2019, 32(1), 83-85.

11. Hansen, J. S., \& Lacourt, P. R. Iatrogenic Cushing's syndrome in a infant due to prolonged use of topical corticosteroids. Case report. Revista chilena de pediatria, 2018, 89(3), 368-372.

12. Tseng, C. L., Chen, Y. T., Huang, C. J., Luo, J. C., Peng, Y. L., Huang, D. F., ... \& Lee, F. Y. Shortterm use of glucocorticoids and risk of peptic ulcer bleeding: a nationwide population-based casecrossover study. Alimentary pharmacology $\mathbb{E}$ therapeutics, 2015, 42(5), 599-606.

13. Reinau, D., Schwenkglenks, M., Früh, M., Signorell, A., Blozik, E., \& Meier, C. R. Glucocorticoids and the risk of peptic ulcer bleeding: Case-control analysis based on Swiss claims data. Drug safety, 2018, 41(7), 725-730.

14. Chen, J., \& Wall, M. Epidemiology and risk factors for idiopathic intracranial hypertension. International ophthalmology clinics, 2014, 54(1).

15. Greer, M., \& Rangel Guerra, R. Benign Intracranial Hypertension (Cerebral Pseudotumor). Medicina universitaria, 2015, 17(66), 2-14.

16. Spiegel, D. R., Arsani, U., \& Le, S. A Case of a Patient with Residual Symptoms of Schizophrenia who Relapsed Following Treatment with the Topical Corticosteroid, Clobetasol: A Review of its Risk of Systemic Absorption and Possibility of Exacerbating Psychosis. Clinical schizophrenia $\mathbb{E}$ related psychoses. 2017.

17. Brusini, P., Tosoni, C., \& Zeppieri, M. Canaloplasty in corticosteroid-induced glaucoma. Preliminary results. Journal of clinical medicine, 2018, 7(2), 31.

18. Hosoda, Y., Hayashi, H., \& Kuriyama, S. Posterior subtenon triamcinolone acetonide injection as a primary treatment in eyes with acute VogtKoyanagi-Harada disease. British Journal of Ophthalmology, 2015, 99(9), 1211-1214..

19. Alderaan, K., Sekicki, V., Magder, L. S., \& Petri, M. Risk factors for cataracts in systemic lupus erythematosus (SLE). Rheumatology international, 2015, 35(4), 701-708.

20. O'Keeffe, D. T., Mikhail, M. A., Lanzino, G., Kallmes, D. F., \& Weinshenker, B. G. Corticosteroid-induced paraplegia-a diagnostic clue for spinal dural arterial venous fistula. JAMA neurology, 2015, 72(7), 833-834.

21. Daniel, E., Pistilli, M., Kothari, S., Khachatryan, N., Kaçmaz, R. O., Gangaputra, S. S., ... \& Jabs, D. A. Risk of ocular hypertension in adults with noninfectious uveitis. Ophthalmology, 2017, 124(8), 1196-1208.

22. Anwar, M. A., Saleh, A. I., Al Olabi, R., Al Shehabi, T. S., \& Eid, A. H. Glucocorticoidinduced fetal origins of adult hypertension: Association with epigenetic events. Vascular pharmacology, 2016, 82, 41-50.

23. Tiwari, A., Al-Robeh, H., Sharma, H., Ammari, Z., Khan, M. S., \& Jaume, J. C. Steroid-induced 
diabetic ketoacidosis in a patient with type 2 diabetes mellitus. AACE Clinical Case Reports, 2018, 4(2), e131-e133.

24. Fathallah, N., Slim, R., Larif, S., Hmouda, H., \& Salem, C. B. Drug-induced hyperglycaemia and diabetes. Drug safety, 2015, 38(12), 1153-1168.

25. Sun, L. Y., \& Chu, X. L. Acute myopathy following intra-muscular injection of compound betamethasone: A case report. Medicine, 2017, 96(34).

26. Mazziotti, G., Formenti, A. M., Frara, S., Doga, M., \& Giustina, A. Vitamin D and GlucocorticoidInduced Osteoporosis. In Vitamin D in Clinical Medicine, 2018, 50, 149-160. Karger Publishers.

27. Shah, S. P., Desai, C. K., Desai, M. K., \& Dikshit, R. K. Steroid-induced central serous retinopathy. Indian journal of pharmacology, 2011, 43(5), 607.

28. Behar-Cohen, F., \& Zhao, M. Corticosteroids and the retina: a role for the mineralocorticoid receptor. Current opinion in neurology, 2016, 29(1), 49-54.

29. van den Heuvel, M. I., van Assen, M. A., Glover, V., Claes, S., \& Van den Bergh, B. R. Associations between maternal psychological distress and salivary cortisol during pregnancy: a mixed-models approach. Psychoneuroendocrinology, 2018, 96, 52-60.

30. Yeung, L., Lima, V. C., Garcia, P., Landa, G., \& Rosen, R. B. Correlation between spectral domain optical coherence tomography findings and fluorescein angiography patterns in diabetic macular edema. Ophthalmology, 2009, 116(6), 1158.
1167.

31. Boyd, S., Brancato, R., \& Straatsma, B. Optical coherence tomography: atlas and text. JP Medical Ltd. 2011.

32. Dakshinamurti, K., Sharma, S. K., \& Geiger, J. D. Neuroprotective actions of pyridoxine. Biochimica et Biophysica Acta (BBA)-Proteins and Proteomics, 2003, 1647(1-2), 225-229.

33. Bacharach, R., Lowden, M., \& Ahmed, A. Pyridoxine toxicity small fiber neuropathy with dysautonomia: a case report. Journal of clinical neuromuscular disease, 2017, 19(1), 43-46.

34. Moudgal, R., Hosseini, S., Colapietro, P., \& Awosika, O. Vitamin B6 Toxicity Revisited: A Case of Reversible Pyridoxine-associated Neuropathy and Disequilibrium. (P4. 021). 2018.

35. van Hunsel, F., van de Koppel, S., van Puijenbroek, E., \& Kant, A. Vitamin B 6 in health supplements and neuropathy: case series assessment of spontaneously reported cases. Drug safety, 2019, 41(9), 859-869.

36. Seth, S., Lewis, A. J., \& Galbally, M. Perinatal maternal depression and cortisol function in pregnancy and the postpartum period: a systematic literature review. BMC pregnancy and childbirth, 2016, 16(1), 124.

37. Mansour, A. M., \& Hamam, R. Operating room central serous chorioretinopathy. SAGE open medical case reports, 2017, 5, 2050313 X17740052. 